\title{
Effects of gonadotrophin concentration on hormone production by theca interna and granulosa cells from bovine preovulatory follicles
}

\author{
A. K. Berndtson, S. E. Vincent and J. E. Fortune* \\ Department and Section of Physiology. College of Veterinary Medicine. Cornell University, Ithaca. \\ NY 14853, USA
}

\section{Introduction}

Mammalian preovulatory follicles produce primarily oestradiol and androgens before the LH and FSH surges. The production of these steroids by the follicle requires both theca and granulosa cells, since theca cells synthesize androgens from progestins but lack aromatizing capacity, whereas granulosa cells aromatize exogenous androgens to oestrogens but lack the ability to convert progestins to androgens (Fortune and Quirk, 1988). In ruminants, the gonadotrophin surge triggers a rapid decrease in oestradiol and androgen production and a marked increase in progesterone and oxytocin biosynthesis (reviewed in Fortune, 1994). It is unclear how changes in gonadotrophin concentrations in vivo regulate this follicular to luteal phase shift in hormone production. Theca and granulosa cells obtained from bovine preovulatory follicles before the gonadotrophin surge 'spontaneously luteinize', as evidenced by increased production of progesterone and oxytocin; high concentrations of gonadotrophins accentuate these changes (Aladin Chandrasekher and Fortune, 1990; Voss and Fortune, 1991). In contrast, similar concentrations of gonadotrophins do not stimulate or maintain thecal androgen production or granulosa oestradiol secretion in vitro (Tsonis et al., 1984; Fortune and Quirk, 1988; Saumande, 1991).

The failure of gonadotrophins to sustain androgen or oestradiol secretion by follicle cells from domestic species in vitro has hampered studies on the regulation of hormone production by developing preovulatory follicles in these species. Oestradiol secretion by granulosa cells from pregnant mares' serum gonadotrophin (PMSG)-treated immature calves is stimulated by very low doses of FSH (Saumande, 1991). The objective of this study was to test the hypothesis that low doses of gonadotrophins maintain follicular secretion of androgens and oestradiol by cultured theca and granulosa cells, whereas higher doses induce luteinization (i.e., progesterone and oxytocin secretion), Therefore, theca interna and granulosa cells were isolated from bovine preovulatory follicles before the gonadotrophin surge and cultured with various doses of LH or FSH.

\section{Materials and Methods}

Holstein heifers $(n=5)$ with normal and regular oestrous cycles were injected i.m. with $25 \mathrm{mg}$ prostaglandin $\mathrm{F}_{2 u}\left(\mathrm{PGF}_{2 u}\right)$ (Lutalyse: Upjohn Co., Kalamazoo, MI) on day 7 of the oestrous cycle (day $0=$ day of oestrus) to initiate luteal regression and the next follicular phase (Voss and Fortune, 1991). The ovary bearing the preovulatory follicle (determined by transrectal ultrasonography) was removed per vaginam $24 \mathrm{~h}$ after $\mathrm{PGF}_{2 \mathrm{a}}$ injection (i.e., $24-36 \mathrm{~h}$ before the expected time of the preovulatory gonadotrophin surge),

The preovulatory follicle was identified and dissected from the ovary; theca interna and granulosa cells were isolated as described in a previous report (Voss and Fortune, 1991). The theca interna was cut into 72 pieces and the pieces transferred into 24-well Costar dishes (three pieces per well); granulosa cells were distributed into 24-well Primaria plates $\left(2 \times 10^{5}\right.$ cells per well). Both theca interna and granulosa 
Table 1. Hormone secretion in the absence of gonadotrophins by theca interna and granulosa cells from bovine preovulatory follicles

\begin{tabular}{|c|c|c|c|c|c|}
\hline \multicolumn{3}{|c|}{ Theca interna ${ }^{a}$} & \multicolumn{3}{|c|}{ Granulosa cells ${ }^{b}$} \\
\hline $\begin{array}{l}\text { Time of culture } \\
\text { (h) }\end{array}$ & $\begin{array}{l}\text { Androstenedione } \\
\text { (ng per culture) }\end{array}$ & $\begin{array}{l}\text { Progesterone } \\
\text { (ng per culture) }\end{array}$ & $\begin{array}{c}\text { Oestradiol } \\
\text { (ng per culture) }\end{array}$ & $\begin{array}{l}\text { Progesterone } \\
\text { (ng per culture) }\end{array}$ & $\begin{array}{c}\text { Oxytocin } \\
\text { (pg per culture) }\end{array}$ \\
\hline $0-24$ & $24.2 \pm 7.8$ & $0.4 \pm 0.1$ & $10.4 \pm 0.5$ & $1.3 \pm 0.2$ & $0.0 \pm 0.0$ \\
\hline $24-48$ & $6.1 \pm 2.7^{c}$ & $1.7 \pm 0.3^{c}$ & $1.2 \pm 0.4^{\mathrm{C}}$ & $7.0 \pm 1.3^{c}$ & $0.0 \pm 0.0$ \\
\hline $48-72$ & $3.1 \pm 1.7^{c}$ & $2.4 \pm 0.5^{c}$ & $0.5 \pm 0.2^{c}$ & $13.0 \pm 2.5^{c}$ & $7.4 \pm 1.1^{c}$ \\
\hline $72-96$ & $1.9 \pm 1.3^{\circ}$ & $4.6 \pm 0.8^{c}$ & & & \\
\hline
\end{tabular}

${ }^{\circ}$ Means \pm SEM of ten theca interna cultures, two from each of five follicles.

bMeans \pm SEM of twelve granulosa cell cultures, four from each of thrce follicles.

'Significantly different relative to $0-24 \mathrm{~h}(P<0.01)$.

cells were cultured in $0.5 \mathrm{ml}$ of defined medium as described by Voss and Fortune (1991). Theca interna pieces were cultured with or without ovine LH $\left(0.5,1,2,4,8,16,32,64,128\right.$ or $256 \mathrm{ng} \mathrm{ml}^{-1}$; NIH-LH-S23) and granulosa cells were cultured with or without ovine FSH $(1,2,4,8,16,32,64$, or $128 \mathrm{ng} \mathrm{ml}^{-1}, \mathrm{NIH}-\mathrm{FSH}-\mathrm{SI7}$ ) at $37^{\circ} \mathrm{C}$ in a humidified incubator gassed with $5 \% \mathrm{CO}_{2}$ and $95 \%$ air. Media were withdrawn and replaced completely with fresh media every $24 \mathrm{~h}$ for $72 \mathrm{~h}$ (granulosa) or $96 \mathrm{~h}$ (theca interna). The collected media were stored at $-20^{\circ} \mathrm{C}$ and later assayed by radioimmunoassay for androstenedione and progesterone in theca interna cultures and oestradiol, progesterone and oxytocin in granulosa cultures (Fortune and Eppig, 1979; Voss and Fortune, 1991).

Hormone concentrations are expressed as ng androstenedione, oestradiol or progesterone per culture \pm SEM and pg oxytocin per culture \pm SEM. If heterogeneity of variance was present, hormone concentrations were log transformed before statistical analysis. The data from the first day of culture $(0-24 \mathrm{~h})$ were subjected to two-factor analysis of variance (ANOVA) with experiment (heifer) and treatment (concentration of $\mathrm{LH}$ or $\mathrm{FSH}$ ) as the two factors. Data from the remaining days of culture were summed over time and the cumulative data were analysed by two-factor ANOVA. Duncan's multiplerange test was used to make comparisons among the means when the ANOVA showed a significant treatment effect.

\section{Results}

Androstenedione secretion by theca interna cultured without LH decreased throughout the culture period, with the greatest decline $(P<0.01)$ occurring between the first and second day (Table 1 ). In contrast, basal progesterone production by theca interna increased $(P<0.01)$ throughout the culture period (Table I). During the first $24 \mathrm{~h}$ of culture, androstenedione production by theca interna cultures was stimulated $(P<0.05)$ by a wide range of LH concentrations $\left(4,8,16,32,64,128\right.$, and $256 \mathrm{ng} \mathrm{ml}^{-1}$; Fig. 1a). However, on days 2-4 of culture, only lower doses of $\mathrm{LH}\left(2\right.$ and $4 \mathrm{ng} \mathrm{ml} \mathrm{m}^{-1}$ ) stimulated $(P<0.05)$ androstenedione secretion above control values (Fig. $1 \mathrm{~b}$ ). Although progesterone production was stimulated $(P<0.05)$ by most concentrations of LH throughout the culture period (Fig. 1 ), the highest doses of $\mathrm{LH}$ were much more effective than the lower stimulatory doses during days 2-4 of culture (Fig. Ib).

Oestradiol production by granulosa cells cultured without FSH decreased $(P<0.01$ ) throughout the culture period, with the largest decline occurring between the first and second day of culture (Table 1). In contrast, progesterone secretion by control cultures increased $(P<0,01)$ throughout the culture period, with the greatest increase occurring between the first and second day of culture (Table I). Basal oxytocin secretion from granulosa cells was negligible for the first 2 days of culture and increased markedly by day 3 (Table 1). During the first $24 \mathrm{~h}$ of culture, FSH had no effect on oestradiol production 


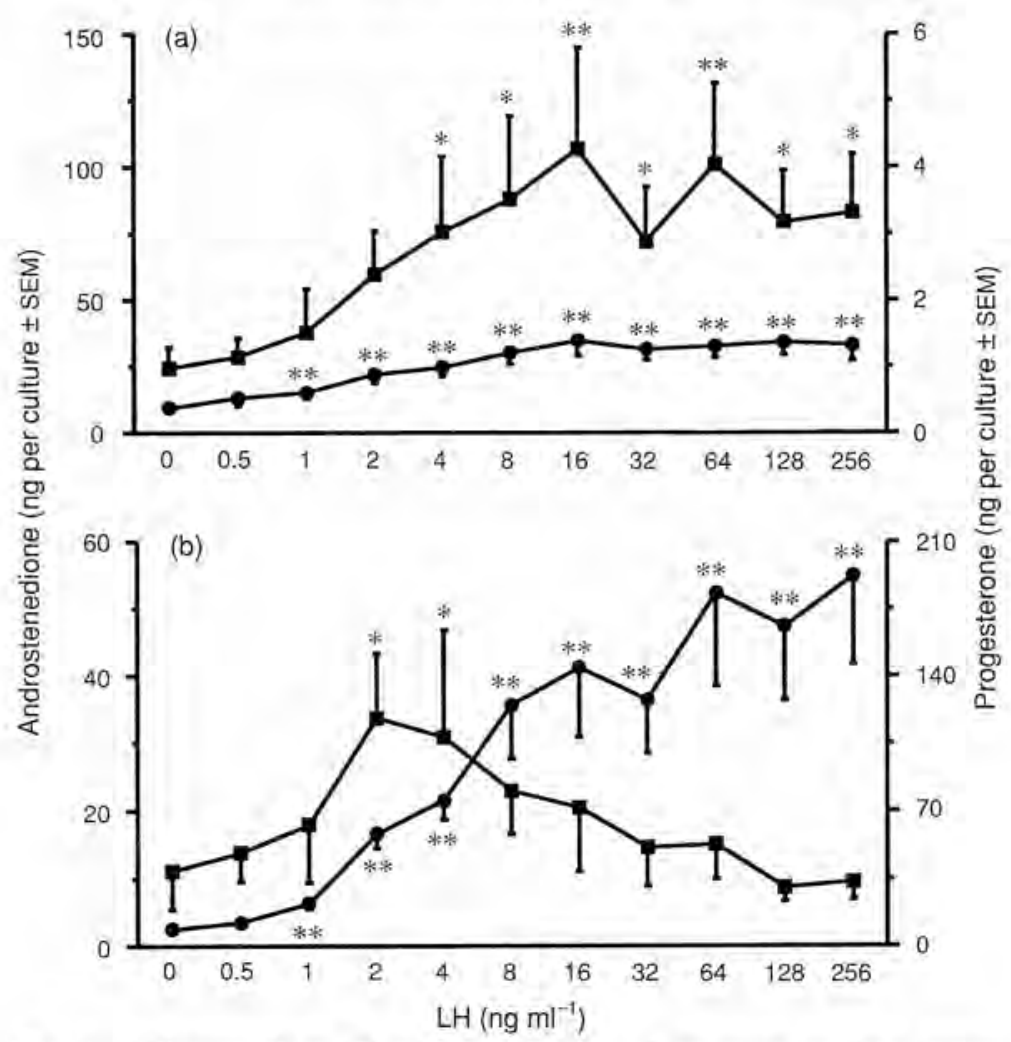

Fig. 1. Androstenedione ( $)$ and progesterone $(\bullet)$ secretion by theca interna isolated from bovine preovulatory follicles before the LH surge and cultured for $96 \mathrm{~h}$ in defined medium alone or with graded doses of $\mathrm{LH}$ ( $n=10$ cultures, two from each of five follicles). (a) Steroid secretion during $0-24 \mathrm{~h}$ of culture; (b) cumulative steroid secretion during $24-96 \mathrm{~h}$ of culture. Data were subjected to ANOYA and Duncan's multiple-range test; significant differences from controls (no LH) are indicated: ${ }^{*} P<0.05,{ }^{*} P<0.01$. Note difference in scale of $y$ axis between panel (a) and (b).

by granulosa cells (Fig. 2a). However, during days 2-3 of culture, the lowest doses of FSH ( $\mathrm{I}$ and $2 \mathrm{ng} \mathrm{ml^{-1 }}$ ) enhanced $(P<0.01)$ oestradiol secretion, whereas higher concentrations of FSH $\left(8-128 \mathrm{ng} \mathrm{ml}^{-1}\right)$ inhibited $(P<0.05)$ oestradiol accumulation (Fig. $\left.2 \mathrm{~b}\right)$. The doses of FSH $(1$ and $2 \mathrm{ng} \mathrm{ml}^{-1}$ ) that stimulated oestradiol production had little effect on progesterone production by granulosa cells (Fig. 2). In contrast, during days $2-3$, the higher doses of FSH $\left(32-128 \mathrm{ng} \mathrm{ml}^{-1}\right.$ ) consistently stimulated progesterone accumulation above controls (Fig. 2b). Oxytocin secretion was low during the first day of culture (data not shown). However, during the last day of culture, oxytocin production was dramatically enhanced $(P<0.01)$ by FSH in a dose-dependent fashion (Fig. 2 b).

\section{Discussion}

The results reveal that only very low doses of LH and FSH maintain functions typical of the follicular phase in bovine theca and granulosa cells, respectively. In contrast, higher doses of gonadotrophins accentuate the tendency of each cell type to 'luteinize' in vitro. These findings are important because they explain why high concentrations of gonadotrophins fail to maintain oestradiol and androstenedione production by cultured follicle cells of domestic species. In addition, these findings mimic the responses 


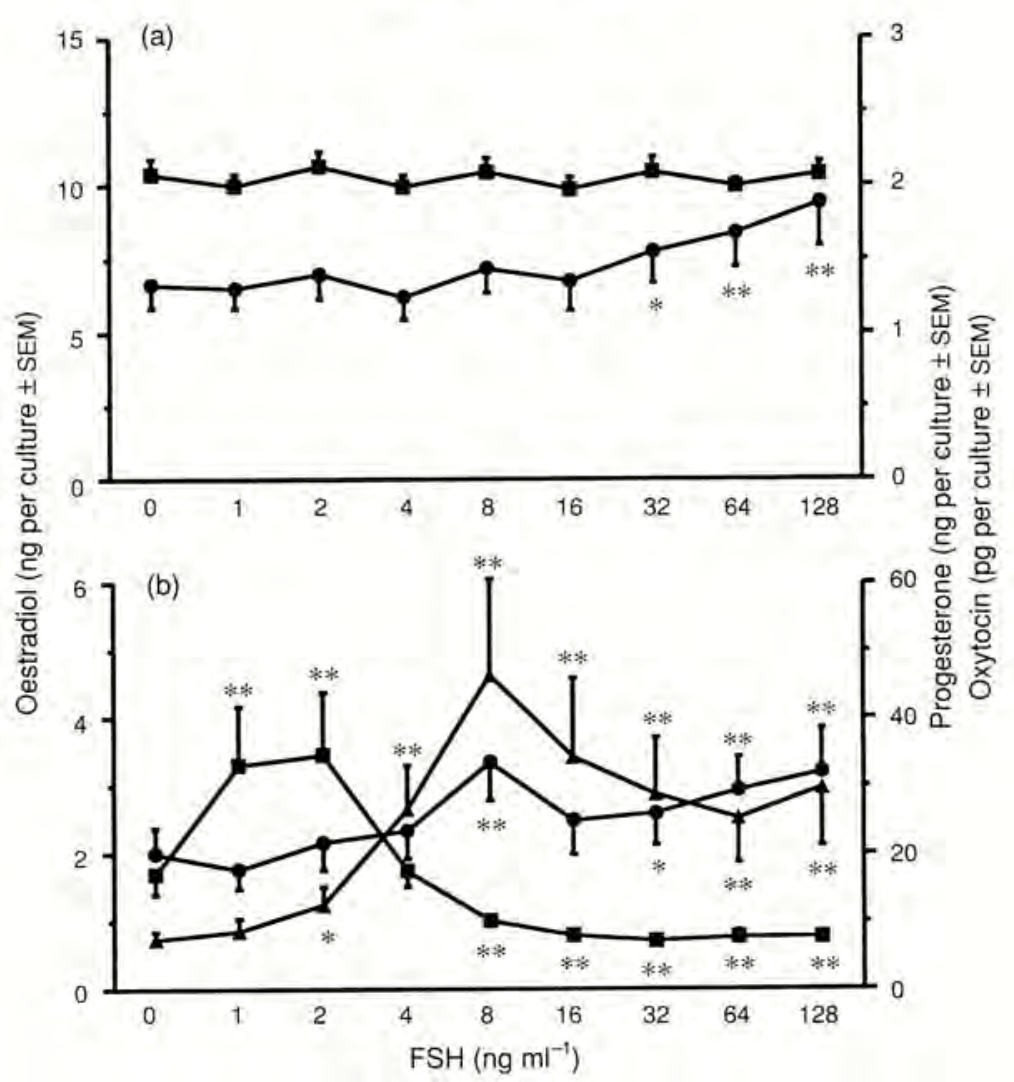

Fig. 2. Oestradiol ( $\mathbf{\bullet})$, progesterone $(\bullet)$, and oxytocin ( $\mathbf{\Lambda}$ ) secretion by granulosa cells $\left(2 \times 10^{5}\right.$ cells per culture) isolated from bovine preovulatory follicles before the LH surge and cultured for $72 \mathrm{~h}$ in defined medium alone or with graded doses of FSH ( $n=12$ cultures, four from each of three follicles). (a) Oestradiol and progesterone secretion during $0-24 \mathrm{~h}$ of culture; (b) curnulative oestradiol and progesterone during $24-72 \mathrm{~h}$ of culture and oxytocin secretion during $48-72 \mathrm{~h}$ of culture. Data were subjected to ANOVA and Duncan's multiple-range test; significant differences from controls (no FSH) are indicated: ${ }^{*} P<0.05, * * P<0.01$. Note difference in scale of $y$ axis between panel (a) and (b).

of bovine preovulatory follicles to basal versus surge concentrations of gonadotrophins in vivo. Therefore, our culture system will provide an experimental model for studying in vitro the cellular and molecular mechanisms that regulate hormone production in follicular cells before and after the preovulatory gonadotrophin surge.

The results show that after the first $24 \mathrm{~h}$ of culture, only a very narrow range of $\mathrm{LH}\left(2-4 \mathrm{ng} \mathrm{ml}^{-1}\right)$ and FSH (1-2 $\mathrm{ng} \mathrm{ml}^{-\mathrm{I}}$ ) concentrations stimulate androstenedione and oestradiol production in bovine theca interna and granulosa cells, respectively. Furthermore, our results demonstrate that higher concentrations of gonadotrophins not only stimulate follicular progesterone and oxytocin production, but also inhibit oestradiol production by granulosa cells. These findings suggest that high and low doses of gonadotrophins regulate hormone production differentially in bovine preovulatory follicles. In contrast, a wider range of gonadotrophin concentrations can sustain androstenedione (Bogovich et al., 1986) and oestradiol (Dorrington et al., 1975; Erickson and Hsueh, 1978; Fortune and Armstrong, 1978; Fortune and Hilbert, 1986) secretion in thecal and granulosa cell cultures from proestrous follicles of rats.

Surge concentrations of LH may activate multiple signal transduction pathways to regulate changes in steroid, prostaglandin and protease production by granulosa cells from preovulatory follicles of rats (Morris and Richards, 1993; Shimamoto et al., 1993). It is possible that the differential effects of low 
versus high doses of gonadotrophins on hormone production in bovine preovulatory follicles could be achieved through activation of different signal transduction pathways. Therefore, our experimental model will be suitable for dissecting in vitro the signal transduction pathways regulated by basal concentrations of gonadotrophins during the follicular phase and those that are activated in response to surge concentrations.

\section{Conclusions}

Very low doses of LH (2-4 $\left.\mathrm{ng} \mathrm{ml}^{-1}\right)$ and FSH $\left(\mathrm{I}-2 \mathrm{ng} \mathrm{ml}^{-1}\right)$ stimulate androstenedione and oestradiol secretion above control concentrations in theca interna and granulosa cell cultures, respectively. In contrast, high concentrations of gonadotrophins promote a shift to progesterone and oxytocin production, characteristic of luteinizing cells. These results explain previous failures, in numerous studies, to achieve sustained stimulation of follicular phase-type functions in cultured cells from domestic animals and provide an experimental system for further study of interactions between gonadotrophins and follicular cells.

The authors thank T. Kimmich, D. Bianchi and R. Saatman for assistance, and G. D. Niswender, D. T. Armstrong, D. Schams, and W. Hansel for providing assay reagents. This work was supported by an NIH grant (HD14584) to J. E. Fortune and by a National Research Service Award (HD07530) to A. K. Berndtson.

\section{References}

Aladin Chandrasekher $X$ and Fortune JE (1990) Effects of oxytocin on steroidogenesis by bovine theca and granulosa cells Endocrinology 127 926-933

Bogovich K, Scales LM, Higginbottom E, Ewing LL and Richards JS (1986) Short term androgen production by rat ovarian follicles and long term steroidogenesis by thecal explants in culture Endocrinology 118 1379-1386

Dorrington JH, Moon YS and Armstrong DT (1975) Estradiol$17 \beta$ biosynthesis in cultured granulosa cells from hypóphysectomized immature rats: stimulation by folliclestimulating hormone Endocrinology 97 1328-1331

Erickson GF and Hsueh AJW (1978) Stimulation of aromatase activity by follicle-stimulating hormone in rat granulosa cells in vivo and in vitro Endocrinology $102 \quad 1275-1282$

Fortune JE (1994) Ovarian follicular growth and development in mammals Biology of Reproduction 50 225-232

Fortune JE and Armistrong DT (1978) Harmonal control of $17 \beta$-estradiol biosynthesis in proestrous rat follicles: estradiol production by isolated theca versus granulosa Endocrinology $102 \quad 227-235$

Fortune JE and Eppig J (J979) Effects of gonadotropins on steroid secretion by infantile and juvenile mouse ovaries in vitro Endocrinology $105760-768$

Fortune JE and Hilbert JL (1986) Estradiol secretion by granulosa cells from rats with four- or five-day estrous cycles: the development of responses to follicle-stimulating hormone versus luteinizing hormone Endocrinology 118 2395-2401

Fortune JE and Quirk SM (1988) Regulation of steroidogenesis in bovine preovulatory follides Journal of Anintal Science 66 (Supplement 2) I-8

Morris JK and Richards JS (1993) Hormone induction of luteinization and prostaglandin endoperoxide synthase-2 involves multiple cellular signaling pathways Endocrinology $133770-779$

Saumande J (1991) Culture of bovine granulosa cells in a chemically defined serum-free medium: the effect of insulin and fibronectin on the response to FSH journal of Steroid Biochemistry and Molecular Biology 38 189-196

Shimamoto T, Yamoto M and Nakano R (1993) Possible involvement of protein kinase $C$ in gonadotropin-induced ovulation in the rat ovary Endocrinology 133 2127-2132

Tsonis CG, Carson RS and Findlay JK (I984) Relationships between aromatase activity, follicular fluid oestradiol-17 $\beta$ and testosterone concentrations, and diameter and atresia of individual ovine follicles Joumal of Reproduction and Fertility $72 \quad 153-163$

Voss AK and Fortune JE (1991) Oxytocin secretion by bovine granulosa cells: effects of stage of follicular development, gonadotropins, and coculture with theca interna Endocrinology $1281991-1999$ 